\title{
Antimicrobial sensitivity of Avibacterium paragallinarum isolates from layers in the special region of Yogyakarta, Indonesia
}

\author{
Ima Fauziah ${ }^{1}$, Widya Asmara² and Agnesia Endang Tri Hastuti Wahyuni² \\ 1. Student of Doctoral Program of Veterinary Science, Faculty of Veterinary Medicine, Universitas Gadjah Mada, \\ Yogyakarta, Indonesia; 2. Department of Microbiology, Faculty of Veterinary Medicine, Universitas Gadjah Mada, \\ Yogyakarta, Indonesia. \\ Corresponding authors: Agnesia Endang Tri Hastuti Wahyuni, e-mail: wahyuni_aeth@ugm.ac.id \\ Co-authors: IF: ima.fauziah@mail.ugm.ac.id, WA: wied_as@ugm.ac.id \\ Received: 14-12-2020, Accepted: 17-03-2021, Published online: 08-05-2021
}

doi: www.doi.org/10.14202/vetworld.2021.1124-1127 How to cite this article: Fauziah I, Asmara W, Wahyuni AETH (2021) Antimicrobial sensitivity of Avibacterium paragallinarum isolates from layers in the special region of Yogyakarta, Indonesia, Veterinary World, 14(5): 1124-1127.

\begin{abstract}
Background and Aim: Infectious coryza (IC) is an upper respiratory disease of chicken caused by Avibacterium paragallinarum. Its clinical symptoms are swollen face and malodorous sinus exudate. This study was conducted to determine the antimicrobial sensitivity of A. paragallinarum isolates from layers in the Special Region of Yogyakarta, Indonesia.

Materials and Methods: The samples used in this study were 30 layers that showed IC symptoms. The colony and cell morphology were observed with Gram staining; then, biochemical tests (catalase, oxidase, urease, indole, and motility tests, and carbohydrate fermentation tests using lactose, maltose, mannitol, and sorbitol) were performed to the suspected colony to identify $A$. paragallinarum. An antibiotic sensitivity test was performed using several antibiotic disks against A. paragallinarum isolates that were cultured on Mueller-Hinton Agar.

Results: Out of 30 samples, 24 samples $(80 \%)$ were found positive for A. paragallinarum. All isolates were sensitive to ampicillin (AMP) and amoxicillin (AML) (100\%), and chloramphenicol (C) (91.6\%). The antibiotics with intermediate sensitivity were enrofloxacin (79.2\%), fosfomycin (75\%), and ciprofloxacin $(54.2 \%)$. The isolates were most resistant to erythromycin (100\%), followed by tetracycline (87.5\%), streptomycin $(83.3 \%)$, doxycycline and kanamycin $(70.8 \%)$, and trimethoprim $(62.5 \%)$.
\end{abstract}

Conclusion: Out of the total samples, 24 samples (80\%) from layers with IC symptoms were identified biochemically as A. paragallinarum. It was sensitive to AMP, AML, and C.

Keywords: antimicrobial susceptibility test, Avibacterium paragallinarum, infectious coryza.

\section{Introduction}

Avibacterium paragallinarum is a Gram-negative bacterium that causes infectious coryza (IC), an upper respiratory tract disease in chickens $[1,2]$. The most common symptoms of IC are facial swelling, infraorbital edema, conjunctivitis, and malodorous nasal and ocular discharge [3]. IC occurs worldwide and causes great economic losses due to decreased egg production (up to $40 \%$ ), increased culling rate of chickens, and increased medical costs [4]. A. paragallinarum can infect all types of chickens in multiage farms [5].

An appropriate selection and use of antibiotics for IC treatment must be considered because they can only reduce the clinical signs of IC but not cure the disease completely [6]. Various sulfonamides and antibiotics are useful in alleviating the severity and course of IC; however, no antibiotics have been found

Copyright: Fauziah, et al. Open Access. This article is distributed under the terms of the Creative Commons Attribution 4.0 International License (http://creativecommons.org/licenses/ by/4.0/), which permits unrestricted use, distribution, and reproduction in any medium, provided you give appropriate credit to the original author(s) and the source, provide a link to the Creative Commons license, and indicate if changes were made. The Creative Commons Public Domain Dedication waiver (http:// creativecommons.org/publicdomain/zero/1.0/) applies to the data made available in this article, unless otherwise stated. to be bactericidal. Erythromycin (E) and oxytetracycline are the two commonly used antibiotics [7]. A. paragallinarum has drug resistance, but there is no specific information about its resistance mechanisms [8].

Multidrug-resistant plasmid from A. paragallinarum isolates has been reported in Taiwan, where more than $75 \%$ of isolates were resistant to streptomycin (S), sulfonamides, kanamycin (K), and neomycin [9]. Relapse often occurs when the treatment is discontinued, and the carrier state is not eliminated [10]. Published data about the antimicrobial susceptibility of A. paragallinarum are limited. Therefore, antimicrobial susceptibility tests for $A$. paragallinarum are needed to determine the appropriate treatment.

This study aimed to determine the antimicrobial sensitivity patterns of $A$. paragallinarum isolates from layers in several farms in the Special Region of Yogyakarta, Indonesia.

\section{Materials and Methods}

\section{Ethical approval}

The samples were collected in accordance with standard collection procedure without hurting or necrotizing animals. 


\section{Study period and location}

The research was conducted from December 2018 to July 2019 in the Microbiology Department, Faculty of Veterinary Medicine, Universitas Gadjah Mada.

\section{Sample collection}

The samples were collected from 30 layers with IC symptoms (malodorous nasal discharge and swollen face) and with no antibiotic treatment after infection. The layers were from several commercial layer farms in the Special Region of Yogyakarta and reared in a battery cage system. All samples were in the layer period (36-56 weeks) and vaccinated against IC.

\section{Isolation and identification of A. paragallinarum}

The nasal exudate samples were cultured on a chocolate agar plate (Oxoid ${ }^{\mathrm{TM}}$, Basingstoke, UK), added with $5 \%$ sheep blood at $80^{\circ} \mathrm{C}$, and incubated in an anaerobic jar for $24-48 \mathrm{~h}$ at $37^{\circ} \mathrm{C}$. Identifications were made based on bacterial colony and cell morphology with Gram staining and biochemical tests (catalase test, oxidase test, urease test, motility test on semisolid media, indole test, and carbohydrate fermentation tests using lactose, maltose, mannitol, and sorbitol) [11-13].

\section{Antimicrobial susceptibility test}

A. paragallinarum was cultured in brain heart infusion broth and incubated in an anaerobic jar at $37^{\circ} \mathrm{C}$ for $24-48 \mathrm{~h}$. A bacterial suspension equivalent to $0.5 \mathrm{McFarland}$ turbidity standard was made and spread onto Mueller-Hilton agar (MHA, Oxoid ${ }^{\mathrm{TM}}$ ). Antibiotic disks were placed on the agar surface. The medium was incubated in an anaerobic jar at $37^{\circ} \mathrm{C}$ for 24-48 $\mathrm{h}$. Twelve antibiotic disks (Oxoid ${ }^{\mathrm{TM}}$ ) were tested: Amoxicillin (AML, $25 \mu \mathrm{g}$ ), ampicillin (AMP, $10 \mu \mathrm{g})$, chloramphenicol $(\mathrm{C}, 30 \mu \mathrm{g})$, trimethoprim (W, $5 \mu \mathrm{g}$ ), Erythromycin (E, $15 \mu \mathrm{g}$ ), tetracycline (TE, $30 \mu \mathrm{g})$, kanamycin $(\mathrm{K}, 30 \mu \mathrm{g})$, ciprofloxacin (CIP, $5 \mu \mathrm{g}$ ), streptomycin (S, $10 \mu \mathrm{g}$ ), fosfomycin (FOS, $50 \mu \mathrm{g}$ ), enrofloxacin (ENR, $5 \mu \mathrm{g}$ ), and doxycycline (DO, $30 \mu \mathrm{g})$. The antimicrobial sensitivity test was performed as recommended by the Clinical Laboratory Standards Institute [14], with some modzone was observed, and the diameter was measured in millimeters. The susceptibility category (sensitive, intermediate, or resistant) was determined by comparing the zone of antibiotics with the zone diameter of Escherichia coli ATCC 25922 as the quality control strain [14]. For FOS, the inhibition zone category was based on the company that supplied the disk (OxoidTM).

\section{Results}

In this study, 24 out of 30 samples (80\%) were found positive for $A$. paragallinarum. The isolates showed tiny, circular, transparent, dewdrop-like Gramnegative coccobacilli colonies based on Gram staining. The isolates were non-motile, negative in catalase, ifications by Chukiatsiri et al. [15]. The inhibition

oxidase, indole, and urease tests, and were able to ferment lactose, maltose, mannitol, and sorbitol based on biochemical tests (Table-1). The sensitivity test of A. paragallinarum to several antibiotics showed different results. All isolates were sensitive to AMP and AML (100\%), and 22 isolates were sensitive to C $(91.6 \%)$. The isolates were intermediately sensitive to ENR (79.2\%), FOS (75\%), and CIP (54.2\%). The isolates were most resistant to $\mathrm{E}(100 \%)$, followed by TE (87.5\%), S (83.3\%), DO and K (70.8\%), and W (62.5\%). The sensitivity test results are shown in Table-2.

\section{Discussion}

The treatment for IC has not been widely studied in Indonesia. There are few reports available about the susceptibility of $A$. paragallinarum isolates to antibiotics in Indonesia [13,16,17]. A total of 30 layers from several farms in the Special Region of Yogyakarta, Indonesia, were used as samples. They showed clinical symptoms, such as infraorbital sinus swelling, malodorous nasal exudate, and decreased egg production, as reported in the previous studies [18-20]. The nasal exudates were cultured on a chocolate agar plate. The colony morphology of 24 isolates showed round, small, transparent, and dewdrop-like colonies, which is similar to the previous studies $[13,19,21]$. Gram staining was done on 24 isolates and showed Gramnegative coccobacilli. The results are similar to the findings of Patil et al. [22] and Deshmukh et al. [23].

Table-1: The biochemical test results of the suspected isolates of Avibacterium paragallinarum.

\begin{tabular}{lcc}
\hline Tests & Results & Positive isolates \\
\hline Catalase & - & 24 \\
Oxidase & - & 24 \\
Urease & - & 24 \\
Indole & - & 24 \\
Motility & - & 24 \\
Lactose & + & 24 \\
Maltose & + & 24 \\
Mannitol & + & 24 \\
Sorbitol & + & 24 \\
\hline
\end{tabular}

Table-2: The results of sensitivity test of Avibacterium paragallinarum isolates from layers against 12 antibiotics.

\begin{tabular}{|c|c|c|c|c|c|c|c|c|}
\hline \multirow[t]{2}{*}{ Antibiotics $(\mu \mathrm{g})$} & \multicolumn{2}{|c|}{$\begin{array}{c}\text { Zone } \\
\text { diameter } \\
(\mathrm{mm})\end{array}$} & \multicolumn{2}{|r|}{$\mathbf{R}$} & \multicolumn{2}{|r|}{ I } & \multicolumn{2}{|r|}{$\mathbf{s}$} \\
\hline & $\mathbf{S}$ & $\mathbf{R}$ & $\mathbf{n}$ & $\%$ & $\mathbf{n}$ & $\%$ & $\mathbf{n}$ & $\%$ \\
\hline Amoxicillin (25) & $\geq 18$ & $\leq 13$ & 0 & 0 & 0 & 0 & 24 & 100 \\
\hline Ampicillin (10) & $\geq 17$ & $\leq 13$ & 0 & 0 & 0 & 0 & 24 & 100 \\
\hline $\begin{array}{l}\text { Chloramphenicol } \\
\text { (30) }\end{array}$ & $\geq 18$ & $\leq 12$ & 2 & 8.3 & 13 & 54.2 & 9 & 91.6 \\
\hline Ciprofloxacin (5) & $\geq 21$ & $\leq 15$ & 1 & 4.2 & 1 & 4.2 & 22 & 37.5 \\
\hline Doxycycline (30) & $\geq 19$ & $\leq 14$ & 17 & 70.8 & 2 & 8.3 & 5 & 20.8 \\
\hline Enrofloxacin (5) & $\geq 23$ & $\leq 16$ & 0 & 0 & 19 & 79.2 & 5 & 20.8 \\
\hline Erythromycin (15) & $\geq 16$ & $\leq 10$ & 24 & 100 & 0 & 0 & 0 & 0 \\
\hline Fosfomycin (50) & $\geq 18$ & $\leq 11$ & 1 & 4.2 & 18 & 75 & 5 & $20 . \varepsilon$ \\
\hline Kanamycin (30) & $\geq 18$ & $\leq 13$ & 17 & 70.8 & 7 & 29.2 & 0 & 0 \\
\hline Streptomycin (10) & $\geq 21$ & $\leq 14$ & 20 & 83.3 & 3 & 12.5 & 1 & 4.2 \\
\hline Tetracycline (30) & $\geq 23$ & $\leq 13$ & 21 & 87.5 & 3 & 12.5 & 0 & 0 \\
\hline Trimethoprim (5) & $\geq 16$ & $\leq 10$ & 15 & 62.5 & 0 & 0 & 9 & 37.5 \\
\hline
\end{tabular}


Then, the isolates underwent biochemical tests, such as catalase, oxidase, urease, indole, motility, and carbohydrate fermentation tests.

A total of 24 isolates identified as A. paragallinarum showed negative results in catalase, oxidase, indole, motility, and urease tests, which were also reported in the previous studies $[11,15,16,20]$. All isolates were able to ferment lactose, maltose, mannitol, and sorbitol, and similar results were reported in other studies $[19,21,22]$. Antimicrobial sensitivity test was done on isolates identified as $A$. paragallinarum. Antimicrobial sensitivity was determined by disk diffusion method.

The sensitivity test results of $A$. paragallinarum showed that the isolates were susceptible to several antibiotics at various levels. All isolates were sensitive to AMP, AML, and C. According to Akter et al. [5], Wahyuni et al. [13], and Han et al. [24], A. paragallinarum had the highest sensitivity to AMP and AML. A. paragallinarum isolates were found to be sensitive to penicillin and few penicillin groups of compounds, such as AMP and AML [23]. Luna-Galaz et al. [25] also reported that all reference isolates used in the study were sensitive to AMP and AML. The sensitivity to $\mathrm{C}$ was consistent with the previous studies [26,27].

The isolates had intermediate sensitivity to ENR, FOS, and CIP. Mohammad et al. [27] also reported that $A$. paragallinarum had intermediate sensitivity to CIP. Other studies reported that A. paragallinarum was sensitive to CIP and ENR [28]. Sensitivity toward FOS has not been described in any studies.

A. paragallinarum had the highest resistance level against E, followed by TE, S, DO, K, and W. Most of $A$. paragallinarum isolates have shown resistance primarily to sulfonamides and partly to aminoglycosides (especially S) and TE [23]. The resistance level against $\mathrm{E}$ was similar to other studies $[9,15]$, whereas the high level of resistance against TE was similar to the study reported by Thenmozi and Malmarugan [29], and Heuvelink et al. [30]. LunaGalaz et al. [25] reported that the Ecuadorian isolates were significantly more resistant to $\mathrm{K}$ and $\mathrm{TE}$ than the Mexican isolates. Resistance to TE and $\mathrm{S}$ was similar to other studies [8,31]. Poernomo et al. [16] reported that A. paragallinarum isolates were resistant to $\mathrm{E}$, neomycin, $\mathrm{S}$, and DO. The resistance to $\mathrm{K}$ and $\mathrm{W}$ was also reported by Wahyuni et al. [13]. Anjaneya et al. [32] reported that $A$. paragallinarum isolates were resistant to TE and DO, with no zone of inhibition.

\section{Conclusion}

Out of the total samples, 24 isolates $(80 \%)$ were identified as $A$. paragallinarum. The sensitivity test results show that $A$. paragallinarum isolates from layers were sensitive to AMP and AML (100\%), and C (91.6\%).

\section{Authors' Contributions}

AETHW: Planned and designed the study. WA: Contributed to the design of research and sampling. IF: Conducted the research and analyzed the results. IF: Prepared the manuscript under the guidance of AETHW and WA. All authors have read and approved the final manuscript.

\section{Acknowledgments}

The authors gratefully acknowledge to Program Rekognisi Tugas Akhir (RTA: 2488/UN1.P.III/DITLIT/PT/2020) Research Directorate, Universitas Gadjah Mada, Yogyakarta, Indonesia, and to the Ministry of Research, Technology, and Higher Education, Republic of Indonesia through Program Pendidikan Magister Menuju Doktor untuk Sarjana Unggul, Indonesia, (PMDSU: 2947/UN1.DITLIT/ DIT-LIT/LT/2019) for the research funding and publication support.

\section{Competing Interests}

The authors declare that they have no competing interests.

\section{Publisher's Note}

Veterinary World remains neutral with regard to jurisdictional claims in published institutional affiliation.

\section{References}

1. Akhtar, S., Bhatti, A.R. and Muhammad, K. (2001) Clinicotherapeutic observations on an outbreak of infectious coryza. Int. J. Agri. Biol., 3(4): 531-532.

2. Nhung, N.T., Chansiripornchai, N. and Carrique-Mas, J.J. (2017) Antimicrobial resistance in bacterial poultry pathogens: A review. Front. Vet. Sci., 4(126): 1-17.

3. Vegad, J.L. and Katiyar, A.K. (2008) Bacterial diseases. In: A Textbook of Veterinary Special Pathology. International Book Distributing Company, New Delhi. p304-306.

4. Blackall, P.J. (2008) Infectious coryza. In: Isolation, Identification and Characterization of Avian Pathogens. $5^{\text {th }}$ ed. American Association of Avian Pathologists, Inc., Georgia. p22-26.

5. Akter, M.R., Khan, M.S.R., Rahman, M.M., Khan, M.A.S. and Kabir, S.M.L. (2013a) Investigation on infectious coryza of layer chicken in Bangladesh with isolation, identification and antibiogram study. Sci. J. Vet. Adv., 2(6): 83-89.

6. Noonkhokhetkong, T., Chukiatsiri, K., Sasipreeyajan, J. and Chansiripornchai, N. (2013) Determination of antimicrobial susceptibility, antimicrobial resistance, genes and in vitro testing of antimicrobial susceptibility of Avibacterium paragallinarum. Thai J. Vet. Med., 43(4): 525-531.

7. Blackall, P.J. and Soriano-Vargas, E. (2013) Infectious coryza and related bacterial infections. In: Diseases of Poultry. $13^{\text {th }}$ ed., Vol. 20. Blackwell Publishing, Iowa. p859-873.

8. Blackall, P.J. (1988) Antimicrobial drug resistance and the occurrence of plasmids in Haemophilus paragallinarum. Avian Dis., 32(4): 742-747.

9. Hsu, Y.M., Shieh, H.K., Chen, W.H., Sun, T.Y. and Shiang, J.H. (2007) Antimicrobial susceptibility, plasmid profiles and haemocin activities of Avibacterium paragallinarum strains. J. Vet. Microbiol., 124(3-4): 209-218.

10. Yamamoto, R. (1978) Infectious coryza. In: Diseases of Poultry. $7^{\text {th }}$ ed. Iowa State University Press, Ames, Iowa. p225-232.

11. Akter, M.R., Khan, M.S.R., Rahman, M.M., Kabir, S.M.L. and Khan, M.A.S. (2016) Epidemic behavior of the etiological agent of infectious coryza in layer chicken of 
Bangladesh with isolation, identification and pathogenicity study. Asian J. Med. Biol. Res., 2(1): 82-94.

12. Jeong, O.M., Kang, M.S., Jeon, B.W., Choi, B.K., Kwon, Y.K., Yoon, S.Y., Blackall, P.J., Lee, H.S., Jung, S.C. and Kim, J.H. (2017) Isolation and characterization of Avibacterium paragallinarum with different nicotinamide adenine dinucleotide requirements. Vet. Microbiol., 205: 62-65.

13. Wahyuni, A.E.T.H., Tabbu, C.R., Artanto, S., Setiawan, D.C.B. and Rajaguguk, S.I. (2018) Isolation, identification, and serotyping of Avibacterium paragallinarum from quails in Indonesia with typical infectious coryza disease symptoms. Vet. World, 11(4): 519-524.

14. Clinical and Laboratory Standards Institute M100-S23. (2013) Performance Standards for Antimicrobial Susceptibility Testing: Twenty-Third Informational Supplement. Clinical and Laboratory Standards Institute, Wayne.

15. Chukiatsiri, K., Sasipreeyajan, J., Blackall, P.J., Yuwatanichsampan, S. and Chansiripornchai, N. (2012) Serovar identification, antimicrobial sensitivity, and virulence of Avibacterium paragallinarum isolated from chickens in Thailand. Avian Dis., 56(2): 359-364.

16. Poernomo, S., Sutarma, Rafiee, M. and Blackall, P.J. (2000) Characterisation of isolates of Haemophilus paragallinarum from Indonesia. Aust. Vet. J., 78(11): 759-762.

17. Tangkonda, E., Tabbu, C.R. and Wahyuni, A.E.T.H. (2014) Sensitivity test of Avibacterium paragallinarum to different antibiotics. J. Kajian Vet., 2(1): 61-64.

18. Muhammad, T.M.N and Sreedevi, B. (2015) Detection of Avibacterium paragallinarum by polymerase chain reaction from outbreaks of infectious coryza of poultry in Andhra Pradesh. Vet. World, 8(1): 103-108.

19. Tangkonda, E., Tabbu, C.R. and Wahyuni, A.E.T.H. (2019) Isolation, identification, and serotyping Avibacterium paragallinarum from commercial layer with snot symptoms. $J$. Sain Vet., 37(1): 27-33.

20. Khatun, M.M., Lijon, M.B., Islam, M.A. and Sultana, N. (2016) Detection of antibiotic-resistant Avibacterium paragallinarum from broiler chickens in Bangladesh. J. Adv. Vet. Anim. Res., 3(2): 173-177.

21. Akter, S., Saha, S., Khan, K.A.,Amin, M.M. and Haque, M.E. (2014) Isolation and identification of Avibacterium paragallinarum from layer chickens in Gazipur, Bangladesh. Microbes Health, 3(1): 9-11.

22. Patil, V.V., Mishra, D.N. and Mane, D.V. (2016). Isolation, characterization and serological study of Avibacterium paragallinarum field isolates from Indian poultry. J. Anim. Poult. Sci., 5(1): 13-20.

23. Deshmukh, S., Banga, H.S., Sodhi, S. and Brar, R.S. (2015) An update on avian infectious coryza: Its reemerging trends on epidemiology, etiologic characterization, diagnostics, therapeutic and prophylactic advancements. J. Dairy Vet. Anim. Res., 2(3): 86-82.

24. Han, M.S., Kim, J.N., Jeon, E.O., Lee, H.R., Koo, B.S., Min, K.C., Lee, S.B., Bae, Y.J., Mo, J.S., Cho, S.H., Jang, H.S. and Mo, I.P. (2016) The current epidemiological status of infectious coryza and efficacy of PoulShot coryza in specific-pathogen-free chickens. J. Vet. Sci., 17(3): 323-330.

25. Luna-Galaz, G.A., Morales-Erasto, V., Penuelas-Rivas, C.G. Blackall, P.J. and Sriano-Vargas, E. (2016) Antimicrobial sensitivity of Avibacterium paragallinarum isolates from four Latin American Countries. Avian Dis., 60(3): 673-676.

26. Priya, P.M., Krishna, S.V., Dineskhumar, V. and Mini, M. (2012) Isolation and characterization of Avibacterium paragallinarum from ornamental birds in Thrissur, Kerala. Int. J. Life Sci., 1(3): 87-88.

27. Mohammad, T.M.N., Sreedevi, B. and Shobhamani, B. (2016) Antibiotic sensitivity pattern of Avibacterium paragallinarum from infectious coryza in Andhra Pradesh. Indian Vet. J., 93(2): 51-53.

28. Durairajan, R., Sharma, M. and Murugan, M.S. (2013) Detection of Avibacterium paragallinarum in commercial poultry and their antibiogram. Tamil Nadu J. Vet. Anim. Sci., 9(4): 332-337.

29. Thenmozhi, V. and Malmarugan, S. (2013) Isolation, identification and antibiogram pattern of Avibacterium paragallinarum from Japanese quails. J. Vet. Anim. Sci., 9(4): 253-258.

30. Heuvelink, A., Wiegel, J., Kehrenberg, C., Dijkman, R., Soriano-Vargas, E. and Feberwee, A. (2018) Antimicrobial susceptibility of Avibacterium paragallinarum isolates from outbreaks of infectious coryza in Dutch commercial poultry flocks, 2008-2017. Vet. Microbiol., 217: 135-143.

31. Rajurkar, G., Ashish, R. and Yadav, M.M. (2010) Antimicrobial sensitivity pattern of Haemophilus paragallinarum isolated from a suspected case of infectious coryza in poultry. Vet. World, 3(4): 177-181.

32. Anjaneya, A., Singh, S.D., Dhama, K., Wani, M.Y. and Gowthaman, V. (2014) Isolation, antibiogram and PCR detection of Avibacterium paragallinarum from poultry flocks of India. J. Pure Appl. Microbiol., 8(5): 4181-4188. 